\title{
Spectrum of eyelid lesions-a histopathological study in South India
}

\author{
(D) Suguna Belur Venugopal ${ }^{1}$, Aparna Muralidhar ${ }^{2}$ \\ ${ }^{1}$ Department of Pathology, Kempegowda Institute Of Medical Sciences, Karnataka, India \\ ${ }^{2}$ Department of Pathology, Bangalore Medical College and Reasearch Centre, Karnataka, India
}

Cite this article as: Venugopal SB, Muralidhar A. Spectrum of eyelid lesions-a histopathological study in South India. J Health Sci Med 2021; 4(1): 13-17.

\begin{abstract}
Aim: Eyelids are complex structures that protect the anterior surface of the globe. Eyelid lesions range from benign, self-limiting conditions to malignant, possibly metastatic tumors.

To assess the histomorphology of various eyelid lesions, determine their frequency, age and sex distribution in our study population and compare them with the other studies.

Material and Method: This is a retrospective study involving 122 patients of either sex presenting with lesions involving the eyelid, reporting to a tertiary care hospital in Karnataka.

Results: We came across $67.72 \%$ neoplastic, $28.34 \%$ inflammatory/infectious, and 3.94\% miscellaneous lesions. There was a slight female predominance with a male to female ratio of $1: 1.18$. The mean age at presentation was 43.7 years, range being 1-90 years. Majority were in their $3 \mathrm{rd}$ and 4 th decades. Among the neoplastic lesions, $90.7 \%$ were benign. The most common benign, malignant and inflammatory lesions were nevus, sebaceous carcinoma and chalazion respectively. Uncommon stromal lesions, such as fibrous histiocytoma and a rare variant of basal cell carcinoma with sebaceous differentiation were encountered.

Conclusions: The frequency of eyelid lesions depends upon age group, source institution, racial and geographic factors. Histopathology remains the mainstay for diagnosis. In addition to determining the malignant potential of a lesion, it reveals its exact nature and structure, thereby influencing management and prognosis.
\end{abstract}

Keywords: Eyelid, nevus, chalazion

\section{INTRODUCTION}

Eyelid lesions are one of the many ophthalmologic conditions encountered in routine clinical practice. Eyelids are crucial to the health of the underlying eye.

Histologically, eyelid is composed of inner tarsal plate containing the meibomian glands, middle layer of orbicularis oculi muscle and surface epithelium. The cilia exit from the middle portion of the lid margin inferiorly. Eccrine and apocrine sweat glands, sebaceous glands of Zeis and hair follicles of the surface lanugo hair are also seen in the lids (1).

Any of the histologic elements can be the origin of the vast spectrum of eyelid lesions.

Most of the eyelid tumors are of cutaneous origin. Others include lymphoid neoplasms, hamartomas, and choristomas (1). Majority develop in adults (2).

Studies in different parts of the world have observed a variable incidence and distribution of eyelid lesions. The present study was conducted to evaluate the overall incidence, age and sex distribution and histopathology of different eyelid lesions in a tertiary care hospital in Karnataka; and compare our findings with published literature.

\section{MATERIAL AND METHOD}

The study was carried out with the permission of Kempegowda Institute of Medical Sciences, Institutional Ethics Committee (Permission granted: 06.12.2016, Decision no: KIMS/IEC/DUPLICATE01/M/2020). All procedures were performed adhered to the ethical rules and the Helsinki Declaration of Principles.

We undertook a three year retrospective hospital based study of 122 patients from January 2016 to December 2019 presenting with eyelid lesions. Purposive sampling was done. The surgically resected specimens were received in $10 \%$ formalin, grossed and processed. Five microns thick sections were taken, stained with haematoxylin\&eosin (H\&E) and evaluated. The identity of the patient was 
kept confidential. The data was subjected to descriptive statistical collation and analysis. Approval of the institution was obtained for the study.

\section{RESULTS}

127 histopathological specimens from 122 patients (few patients had more than one lesion) were analysed.

The mean age at presentation was 43.7 years, range being from 1-90 years. Peak was noticed in the third and fourth decades of life.

Most lesions were inflammatory/infectious amounting to $28.34 \%$, closely followed by adnexal lesions (27.6\%). Amongst the 86 neoplastic lesions, $90.7 \%(n=78)$ were benign and $9.3 \%(n=8)$ were malignant. The most common benign and malignant tumors were nevus and sebaceous gland carcinoma (SGC) respectively. Miscellaneous lesions included two cases of blepahrochalasis, one case each of ectropion, entropion and burn injury.

The distribution of various lesions is depicted in Table $\mathbf{1}$.

\section{Table 1. Distribution of eyelid lesions}

\begin{tabular}{|lccc|}
\hline Origin & Benign & Malignant & Total \\
\hline Epidermal & 33 & 02 & 35 \\
Adnexal & 24 & 06 & 30 \\
Mesenchymal & 21 & 0 & 21 \\
Inflammatory/infectious & 36 & 0 & 36 \\
Miscellaneous & 05 & 0 & 05 \\
\hline
\end{tabular}

The graph depicts the sex distribution of different lesions. Overall, a slight female predominance with a male to female ratio of 1:1.18 was observed. Benign epidermal tumors mainly affected 3rd and 4th decades of life, while benign adnexal tumors were most common between 4160 years of age. Stromal lesions had a wide range of age distribution from 1-83 years. Infectious/inflammatory lesions peaked at 21-40 years.

Of the 33 benign epidermal lesions, nevi were the most common (48.5\%, $\mathrm{n}=16$ ) and affected females predominantly. This was followed by squamous papilloma $(36.37 \%, \mathrm{n}=12)$, which showed a male predominance. There were two cases each of seborrheic keratosis and cutaneous horn, and one case of lichen planus pigmentosus.

Microscopically, intradermal nevus shows clusters of round to spindle cells with small, regular nuclei in the dermis (Figure 1a). Compound nevus shows a junctional component along with intradermal clusters. We encountered 13 cases of intradermal nevi and three cases of compound nevi.
The most common benign adnexal tumor was epidermal inclusion cyst $(33.33 \%, \mathrm{n}=8)$ followed by eccrine cyst $(16.67 \%, n=4)$. The other cystic lesions observed were sebaceous cyst $(n=3)$, cyst of Moll $(n=2)$; and one case each of retention cyst, tenon's cyst, cyst of Zeis, eccrine hidrocystoma and apocrine hidrocystoma. Amongst the sweat gland tumors, there was one case each of chondroid syringoma and nodular hidradenoma.

Benign vascular lesions comprising of seven cases of capillary hemangioma (Figure 1b) were the most common stromal lesions. Few cases of pyogenic granuloma, xanthelasma, hamartoma and neurofibroma were also noted. There was one case each of fibrous histiocytoma, xanthogranuloma and scar tissue.

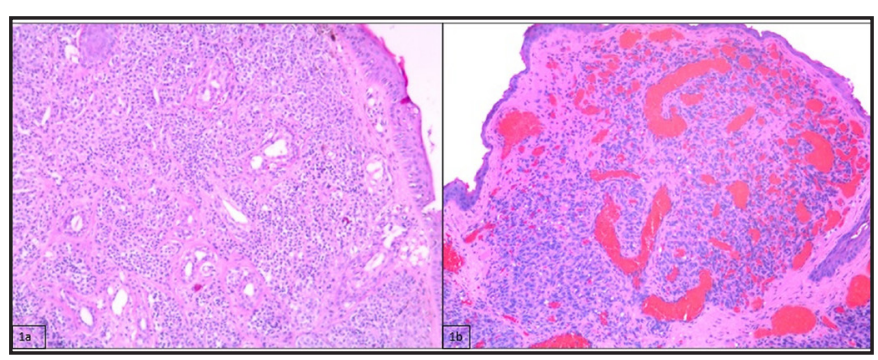

Figure 1. (a) Photomicrograph of intradermal nevus, H\&E, 4x. (b) Photomicrograph of capillary hemangioma, H\&E, 4x.

Figures 2 and 3 show the histologic images of few of the above lesions.

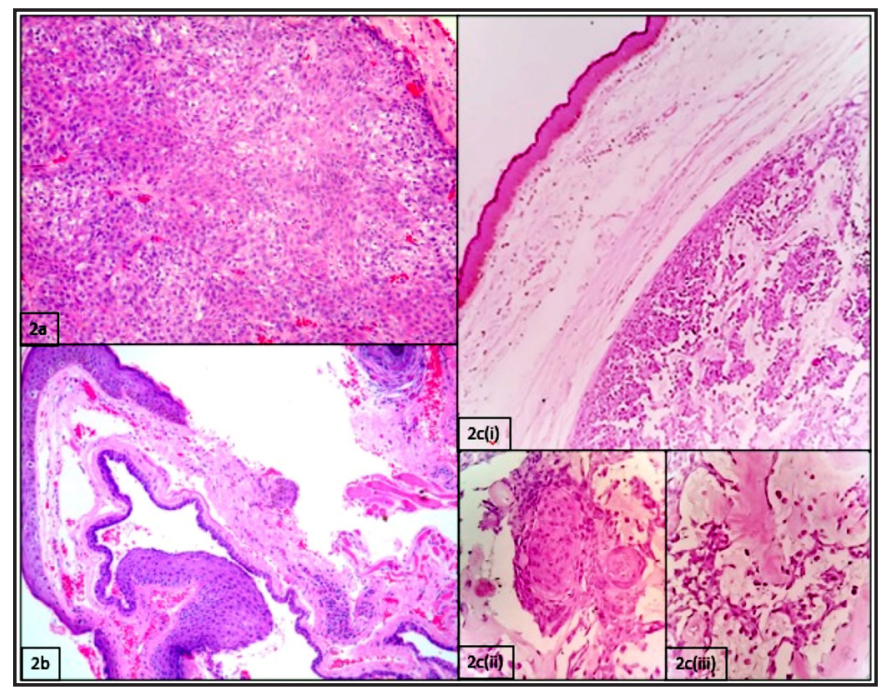

Figure 2. (a) Photomicrograph of nodular hidradenoma showing cells with clear to eosinophilic cytoplasm, H\&E, 4x. (b) Photomicrograph of apocrine hidrocystoma, H\& E, 4x. (c(i)) Photomicrograph of chondroid syringoma, H\&E, 4x. (c(ii)) Photomicrograph of chondroid syringoma showing focal squamous differentiation H\&E, 40x (c(iii)) Photomicrograph of chondroid syringoma showing chondromyxoid matrix, H\&E, 40x. 


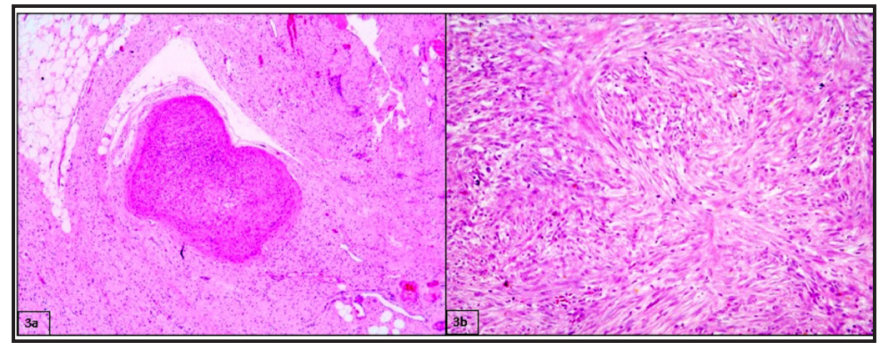

Figure 3. (a) Photomicrograph of plexiform neurofibroma, H\&E, 4x. (b) Photomicrograph of fibrous histiocytoma, H\&E, 4x.

We came across eight malignant eyelid tumors, six of which were sebaceous gland carcinoma (Figure 4). There was one case each of squamous cell carcinoma (SCC) and basal cell carcinoma (BCC). SGC involved only females above 40 years of age with predilection for right eyelid. SCC of the right eyelid as a contiguous spread of conjunctival ocular surface squamous neoplasia was seen in an 80 year old male. Specimen from right eyelid of a 65 year old female showed $\mathrm{BCC}$ with sebaceous differentiation, a rare variant of BCC.

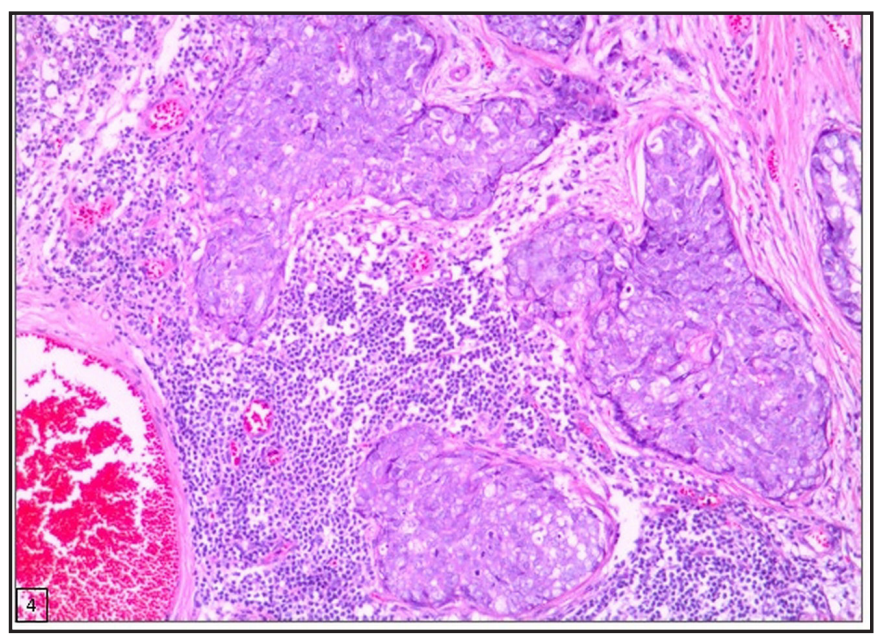

Figure 4. Photomicrograph of sebaceous carcinoma, H\&E, 40x.

$83.33 \%(\mathrm{n}=30)$ of the lesions in infectious/inflammatory category were chalazia (Figure 5a), more common in males and affected individuals aged 21-40 years predominantly. We encountered three cases of molluscum contagiosum (Figure $5 \mathbf{b}$ ), two of which were seen in children and one in a 28 year old male.

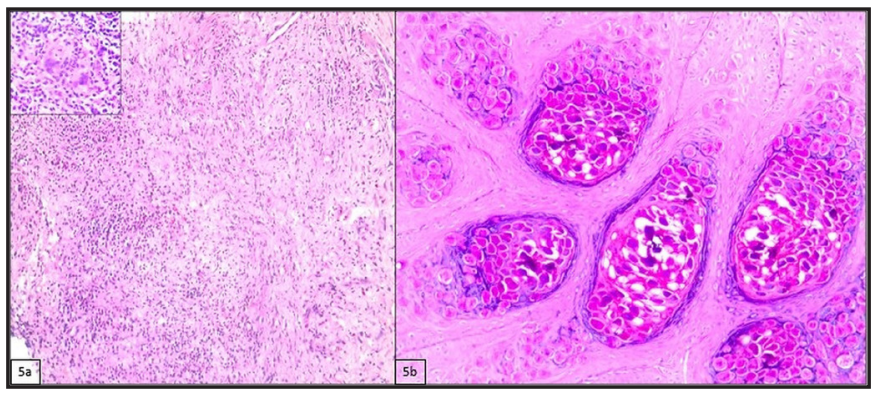

Figure 5. (a) Photomicrograph of chalazion, $H \& E, 4 x$.

Inset - multinucleate giant cell, H\&E, 40x. (b) Photomicrograph of molluscum contagiosum, $\mathrm{H} \& \mathrm{E}, 4 \mathrm{x}$.
The miscellaneous cases included ectropion, entropion, blepharochalasis and burn injury.

\section{DISCUSSION}

Eyelid lesions encompass a variety of inflammatory and neoplastic growths.

Histologically, eyelid tumors can be classified based on the tissue or cell of origin into the following categories: epidermal, adnexal, stromal, secondary, metastatic, inflammatory/infections. Based on their behaviour, they can be benign or malignant (3). Significant majority of the neoplastic growths are benign and constitute $82-98 \%$ of all neoplasms (4).

In our study, the mean age at presentation of benign and malignant lesions were 45.9 years and 61.5 years respectively, correlating well with other studies (5-7).

The gender distribution is variable globally. Few studies $(5,8,9)$ noticed a male predominance, but most studies $(6,7,10-13)$ including ours have observed a female predominance. Amongst the 86 neoplastic lesions, 90.7\% were benign, in accordance with published literature $(3,4)$.

Melanocytic nevus was the most common benign lesion, similar to few other studies $(5,6,9)$. However, Coroi MC et al. (10) and Gupta P et al. (11) observed squamous papilloma and sebaceous cyst to be more common respectively (Table 2).

\begin{tabular}{|c|c|c|c|c|c|}
\hline Study & คำ & ᄋ。 & ○。 & $\begin{array}{c}\text { Most } \\
\text { common } \\
\text { benign } \\
\text { tumor }\end{array}$ & $\begin{array}{c}\text { Most } \\
\text { common } \\
\text { malignan } \\
\text { tumor }\end{array}$ \\
\hline $\begin{array}{l}\text { Deprez M. } \\
\text { et al. (12) }\end{array}$ & 84 & 16 & - & $\begin{array}{l}\text { Squamous } \\
\text { papilloma }\end{array}$ & $\begin{array}{l}\text { Basal cell } \\
\text { carcinoma }\end{array}$ \\
\hline $\begin{array}{l}\text { Bagheri A. } \\
\text { et al. (5) }\end{array}$ & 45 & 55 & - & Nevus & $\begin{array}{l}\text { Basal cell } \\
\text { carcinoma }\end{array}$ \\
\hline $\begin{array}{l}\text { Xu XL. } \\
\text { et al. (6) }\end{array}$ & 62.1 & 13.8 & 24.1 & Nevus & $\begin{array}{l}\text { Basal cell } \\
\text { carcinoma }\end{array}$ \\
\hline $\begin{array}{l}\text { Asproudis I. } \\
\text { et al. (22) }\end{array}$ & 53.1 & 41.3 & 5.6 & Cyst & $\begin{array}{l}\text { Basal cell } \\
\text { carcinoma }\end{array}$ \\
\hline $\begin{array}{l}\text { Coroi MC. } \\
\text { et al. (9) }\end{array}$ & 45.8 & 54.2 & - & $\begin{array}{l}\text { Squamous } \\
\text { papilloma }\end{array}$ & $\begin{array}{l}\text { Basal cell } \\
\text { carcinoma }\end{array}$ \\
\hline $\begin{array}{l}\text { Gupta P. } \\
\text { et al. (10) }\end{array}$ & 64 & 36 & - & $\begin{array}{c}\text { Sebaceous } \\
\text { cyst }\end{array}$ & $\begin{array}{l}\text { Sebaceous } \\
\text { carcinoma }\end{array}$ \\
\hline $\begin{array}{l}\text { Patel M. } \\
\text { et al. (8) }\end{array}$ & 56 & 44 & - & Nevus & $\begin{array}{l}\text { Sebaceous } \\
\text { carcinoma }\end{array}$ \\
\hline Present & 61.42 & 6.3 & 28.34 & Nevus & $\begin{array}{l}\text { Sebaceous } \\
\text { carcinoma }\end{array}$ \\
\hline
\end{tabular}


Epidermal inclusion cysts and sebaceous cysts were common cystic lesions with male predominance observed in our study as well as by Bagheri A et al. (5). The epithelial cells lining the sebaceous cyst possess no clearly visible intercellular bridges with amorphous eosinophilic material in the cavity, while in epidermal inclusion cyst, the cells are stratified squamous epithelium with loose laminated keratin in the lumen (1).

Benign tumours originating from skin appendages of the eyelid are rare and frequently have apocrine or eccrine differentiation (14), most common being hidrocystomas (1). We came across twenty four benign adnexal lesions. Very few other studies on eyelid neoplasms in our country have reported these (9).

Review of eyelid tumors by Jacob Pe'er (3) states capillary hemangioma and pyogenic granuloma to be the most common vascular and acquired vascular lesions of the eyelid respectively. A similar observation was made by us.

Chalazion is a chronic, localized swelling of the eyelid typically affecting the meibomian glands or glands of Zeis. In a review by Deprez et al. (15), chalazia represented nearly half of all eyelid lesions in Switzerland. In ours as well as a retrospective study in Saudi population (13), they represented about one fourth of all the lesions.

The global distribution of eyelid malignancies is varied. It is reported that around $90 \%$ of the malignant eyelid tumors are basal cell carcinomas, while sebaceous gland and squamous cell carcinomas are uncommon. (16-18). However, studies from Asian countries report a higher incidence of SGC. $(3,12,17)$. There is wide racial and probable geographical variation reported in the incidence of the eyelid tumors. (4). A study on sebaceous carcinoma of ocular adnexa (18) proposed that the incidence of SGC is higher in Asian population compared to Caucasians and this could be related to genetics and racial predisposition for SGC in Asians. However, a more recent study by Dasgupta et al. (19) proposed that Asian ancestry is not a risk factor for developing sebaceous carcinoma.

Indian studies $(7,9,11)$ have observed SGC as the most common eyelid malignancy with a female predominance. This is exemplified by our study as well. SGC is generally a disease of elderly patients, more common in women (3). All cases of SGC were females, mean age at presentation being 57.8 years, similar to Kaliki $S$ et al. (7) The results of two hospital based studies in Nagpur $(19,20)$ showed BCC to be most common eyelid malignancy. Many studies in America and Europe have found BCC to be very common $(10,15,22,23)$.
BCC with sebaceous differentiation is a rare variant, histopathologically characterised by nests of pleomorphic basaloid cells invading the dermis with peripheral palisading, retraction clefts at the tumor stroma interface, brisk mitotic activity and sebaceous duct-like structures. Vacuolated cells, with foamy, bubbly cytoplasm and scalloped or starry nuclei, suggestive of sebocytes (sebaceous differentiation) are scattered within the nests. These vacuolated cells are immunohistochemically positive for epithelial membrane antigen (EMA) $(24,25)$. In contrast, sebaceoma shows monomorphic basaloid cells, minimal or absent mitotic activity and lack of peripheral palisading and retraction clefts. Sebaceous carcinoma also shows absence of peripheral palisading and retraction clefts $(25,26)$.

Ectropion and entropion are structural abnormalities that can be congenital or senile. An accentuation of the aging changes may result in an ectropion (turningout) or an entropion (turning-in) of the lower lid. Histologically, both ectropion and entropion show chronic non granulomatous inflammation and cicatrisation of the skin and conjunctiva (1). We encountered two such cases.

\section{CONCLUSION}

The eyelid is made up of different types of tissues, each of which can be pathologically affected. Most of the lesions are benign. The distribution of this wide spectrum of lesions shows racial and geographic variation. Data from published literature in our country show variable incidence of different types of eyelid tumors, thereby emphasising the need for further studies to determine the geographic pattern. Our study reiterates the geographic variation in the incidence of eyelid tumors, especially sebaceous carcinoma, which was the most frequent eyelid malignancy. Histopathologic examination enables accurate diagnosis, thereby enhancing patient care.

\section{ETHICAL DECLARATIONS}

Ethics Committee Approval: The study was carried out with the permission of Kempegowda Institute of Medical Sciences, Institutional Ethics Committee (Permission granted: 06.12.2016, Decision no: KIMS/ IEC/DUPLICATE01/M/2020).

Informed Consent: Because the study was designed retrospectively, no written informed consent form was obtained from patients.

Referee Evaluation Process: Externally peer-reviewed.

Conflict of Interest Statement: The authors have no conflicts of interest to declare. 
Financial Disclosure: The authors declared that this study has received no financial support.

Author Contributions: All of the authors declare that they have all participated in the design, execution, and analysis of the paper, and that they have approved the final version.

\section{REFERENCES}

1. Yanoff M, Sassani JW. Ocular Pathology. 7th ed. Philadelphia: Elsevier Saunders; 2015.

2. Folberg R. Tumors of the eye and ocular adnexa. In: Diagnostic histopathology of tumors. Fletcher CDM. 4th ed. Philadelphia: Elsevier Saunders; 2013: 2086-116.

3. Pe'er J. Pathology of eyelid tumors. Indian J Ophthalmol 2016; 64: 177-90.

4. Singh U, Kolavali RR. Overview of eyelid tumors. In: Surgical ophthalmic oncology. Chaugule SS, Honavar SG, Finger PT (eds). Switzerland: Springer; 2019: 3-10.

5. Bagheri A, Tavakoli M, Kanaani A, et al. Eyelid masses: a 10-year survey from a tertiary eye hospital in Tehran. Middle East Afr J Ophthalmol 2013; 20: 187-92.

6. Xu XL, Li B, Sun XL, et al. Eyelid neoplasms in the Beijing Tongren Eye Centre between 1997 and 2006. Ophthalmic Surg Lasers Imaging 2008; 39: 367-72.

7. Kaliki S, Bothra N, Bejjanki KM, et al. Malignant eyelid tumors in India: a study of 536 Asian Indian patients. Ocul Oncol Pathol 2019; 5: 210-19. doi:10.1159/000491549

8. Lee SB, Eong KGA, Saw SM, Chan TK, Lee HP. Eye cancer incidence in Singapore. Br J Ophthalmol 2000; 84: 767-70

9. Patel M, Chavda BH, Shah Y, Bhavsar M. Study of incidence, occurrence, origin, and histological types of eyelid tumors at Tertiary Care Hospital in Ahmedabad. Int J Sci Stud 2019; 6: 16-9.

10. Coroi MC, Roşca E, Muţiu G, Coroi T, Bonta M. Eyelid tumors: histopathological and clinical study performed in County Hospital of Oradea between 2000-2007. Rom J Morphol Embryol 2010; 51: 111-5.

11. Gupta P, Gupta RC, Khan L. Profile of eyelid malignancy in a Tertiary Health Care Center in North India. J Can Res Ther 2017; 13: 484-6.

12. Wang JK, Liao SL, Jou JR, et al. Malignant eyelid tumors in Taiwan. Eye 2003; 17: 216-20.

13. Al-Faky YH. Epidemiology of benign eyelid lesions in patients presenting to a teaching hospital. Saudi J Ophthalmol 2012; 26 211-6.

14. Ozdal PC, Callejo SA, Codère F, Burnier MN Jr. Benign ocular adnexal tumours of apocrine, eccrine or hair follicle origin. Can J Ophthalmol. 2003; 38: 357-63.

15. Deprez M, Uffer S. Clinicopathological features of eyelid skin tumors. A retrospective study of 5504 cases and review of literature. Am J Dermatopathol 2009; 31: 256-62.

16. Al-Buloushi A, Filho JP, Cassie A, Arthurs B, Burnier MN Jr. Basal cell carcinoma of the eyelid in children: a report of three cases. Eye 2005; 19: 1313-4.

17. Shields JA, Demirci H, Marr BP, Eagle RC Jr, Shields CL. Sebaceous carcinoma of the eyelids: Personal experience with 60 cases. Ophthalmology 2004; 111: 2151-7.
18. Ni C, Searl SS, Kuo PK, Chu FR, Chong CS, Albert DM. Sebaceous cell carcinomas of the ocular adnexa. Int Ophthalmol Clin 1982; 22: 23-61.

19. Dasgupta T, Wilson LD, Yu JB. A retrospective review of 1349 cases of sebaceous carcinoma. Cancer 2009; 115: 158-65.

20. Kale SM, Patil SB, Khare N, Math M, Jain A, Jaiswal S. Clinicopathological analysis of eyelid malignancies-a review of 85 cases. Indian J Plast Surg 2012; 45: 22-8.

21.Jahagirdar SS, Thakre TP, Kale SM, Kulkarni H, Mamtani M. A clinicopathological study of eyelid malignancies from central India. Indian J Ophthalmol 2007; 55: 109-12.

22. Paul S, Vo DT, Sikliss RZ. Malignant and benign eyelid lesions in San Francisco: Study of a diverse urban population. Am. J. Clin Med 2011; 8: 40-6.

23. Asproudis I, Sotiropoulos G, Gartzios C, et al. Eyelid Tumors at the University Eye Clinic of Ioannina, Greece: A 30-year Retrospective Study. Middle East Afr J Ophthalmol 2015; 22: 230-2.

24. Misago N, Suse T, Uemura T, Narisawa Y. Basal cell carcinoma with sebaceous differentiation. Am J Dermatopathol 2004; 26: 298-303.

25. Steffen $\mathrm{CH}$, Ackerman AB. Basal-cell carcinoma with sebaceous differentiation. In: Steffen CH, Ackerman AB, editors. Neoplasms with Sebaceous Differentiation. Philadelphia, PA: Lea\&Febiger; 1994. pp 577-96.

26. Steffen $\mathrm{CH}$, Ackerman AB. Sebaceous carcinoma. In: Steffen $\mathrm{CH}$, Ackerman AB, editors. Neoplasms with sebaceous differentiation. Philadelphia, PA: Lea\&Febiger; 1994. pp 487-74. 